\title{
Pansteatitis associated with high levels of polychlorinated biphenyls in a wild loggerhead sea turtle Caretta caretta
}

\author{
J. Orós ${ }^{1, *}$, P. Monagas ${ }^{1}$, P. Calabuig ${ }^{2}$, O. P. Luzardo ${ }^{3}$, M. Camacho ${ }^{1}$ \\ ${ }^{1}$ Department of Morphology, Veterinary Faculty, University of Las Palmas de Gran Canaria (ULPGC), \\ 35416 Arucas (Las Palmas), Spain \\ ${ }^{2}$ Tafira Wildlife Rehabilitation Center (Cabildo de Gran Canaria), Tafira Baja, 35017 Las Palmas de Gran Canaria, Spain \\ ${ }^{3}$ Toxicology Unit, Department of Clinical Sciences, University of Las Palmas de Gran Canaria (ULPGC), PO Box 550, \\ 35080 Las Palmas de Gran Canaria, Spain
}

\begin{abstract}
We describe the morphologic and toxicological findings in a case of pansteatitis in a stranded loggerhead sea turtle Caretta caretta. At necropsy, a large amount of adipose tissue in the celomic cavity showing very firm, yellow to orange irregular formations was observed. Histological lesions ranged from the infiltration of necrotic fat by scarce multinucleated giant cells and numerous macrophages containing xylene-insoluble lipopigment inclusions to the presence of several granulomas characterized by an irregular central necrotic area consisting of lipopigment surrounded by numerous multinucleated giant cells. Microbiological cultures were negative. Celomic fat was analyzed for PCBs and DDTs, resulting in very high levels of PCB 138, 153, 180 $209\left(3170,2830,980\right.$ and $1190 \mathrm{ng} \mathrm{g}^{-1}$, respectively). Although a nutritional cause cannot be ruled out, the high levels of PCBs detected in the celomic fat could have induced lipid peroxidation in adipocytes, resulting in cell damage, deposition of ceroid pigment and inflammatory response. This is the first report of pansteatitis in a wild sea turtle.
\end{abstract}

KEY WORDS: Contaminants $\cdot$ PCBs $\cdot$ DDTs $\cdot$ Disease $\cdot$ Lipid peroxidation Resale or republication not permitted without written consent of the publisher

\section{INTRODUCTION}

All species of sea turtles are included in the Red List of the World Conservation Union (IUCN 2012). In recent years, increased efforts have been devoted to the conservation of sea turtles, including medical management and pathological studies on stranded animals (Work et al. 2004, Orós et al. 2005). Although the most common species in the Canary Islands is the loggerhead turtle, evidence of a decline in the population of loggerheads in the Canary Islands has been reported (Blanco \& González 1992).

Pansteatitis describes generalized inflammation of the subcutaneous and intra-abdominal fat, mainly associated with vitamin E deficiency and with the same etiologies described for panniculitis (German et al. 2003). Among the class Reptilia, pansteatitis has only been described in captive American alligators Alligator mississippiensis (Larsen et al. 1983), farmed (Huchzermeyer 2003) and wild Nile crocodiles Crocodylus niloticus (Bouwman et al. 2009), and captive olive ridley sea turtles Lepidochelys olivacea (Manawatthana \& Kasorndorkbua 2005).

Although there are numerous studies reporting baseline levels of contaminants in several species of sea turtles from different geographical areas, available data on the effects of these contaminants on diseases and lesions of sea turtles are scarce 
(Keller et al. 2004b, Swarthout et al. 2010, Orós et al. 2012).

Since 1994, the Veterinary Faculty at the University of Las Palmas de Gran Canaria (ULPGC) has been carrying out a survey of lesions and causes of mortality among sea turtles stranded on the coasts of the Canary Islands. This paper describes morphologic and toxicological findings in a case of pansteatitis in a stranded loggerhead sea turtle Caretta caretta.

\section{MATERIALS AND METHODS}

A subadult female loggerhead sea turtle was found in March 2009 floating off the coast of Gran Canaria, Canary Islands. The turtle weighed $19.2 \mathrm{~kg}$ and had a curved carapace of length and width 55.7 and $57.3 \mathrm{~cm}$, respectively, and a straight carapace length of $54 \mathrm{~cm}$ and width of $52.1 \mathrm{~cm}$. The turtle was lethargic, weak, and non-responsive to external stimuli, and was floating in a non-horizontal position, with a lifting of the cranial part of the carapace. The animal died before a health evaluation and medical management could be done at the Tafira Wildlife Rehabilitation Center (TWRC), and the carcass was submitted to the Veterinary Faculty, ULPGC, for post mortem examination.

Necropsy was carried out using the procedures previously described (Orós \& Torrent 2001, Flint et al. 2009). Macroscopic lesions were recorded and tissue samples from all major organs were fixed in $10 \%$ neutral buffered formalin, embedded in paraffin, sectioned at $5 \mu \mathrm{m}$ for light microscopy and stained with hematoxylin and eosin (HE). Periodic acidSchiff (PAS) and Ziehl-Neelsen (ZN) stains were used to stain selected sections.

Celomic fat was collected during necropsy, wrapped in aluminium foil and stored at $-20^{\circ} \mathrm{C}$ until analysis. Polychlorinated biphenyls (IUPAC nos. 28, 31, 52, 101, 138, 153, 180, and 209) and DDT and its metabolites (OC-DDTs) (o, $p^{\prime}$-DDT, $o, p^{\prime}$-DDE, and $o, p^{\prime}$-DDD) were analyzed according to the method described by Tanabe et al. (1994). The validity of analytical methods was confirmed with Standard Reference Materials (CARP-2: ground whole carp Cyprinus carpio) obtained from the National Research Council of Canada (Table 1).

Aliquots (4 to $7 \mathrm{~g}$ ) of the homogenized samples were ground with anhydrous sodium sulphate in a mortar, and extracted using Soxhlet apparatus for $6 \mathrm{~h}$ with $300 \mathrm{ml}$ of diethyl ether:hexane (3:1) solvent mixture. Extracts were concentrated in volume to $10 \mathrm{ml}$
Table 1. Precision and accuracy of analytical methods obtained using a certified ground whole carp Cyprinus carpio (CARP-2). Concentrations are given in $\mathrm{ng} \mathrm{g}^{-1}$ wet weight. Number of replicates: 3

\begin{tabular}{|lcc|}
\hline & \multicolumn{2}{c}{ CARP-2 } \\
\cline { 2 - 3 } & Certified & \multirow{2}{*}{ Found } \\
\hline PCB 28 & $34 \pm 7.2$ & $31.5 \pm 2.6$ \\
PCB 52 & $138 \pm 43$ & $120.1 \pm 11.1$ \\
PCB 101 & $145 \pm 48$ & $148.7 \pm 18.3$ \\
PCB 138 & $103 \pm 30$ & $99.8 \pm 16.8$ \\
PCB 153 & $105 \pm 22$ & $115.2 \pm 14.8$ \\
PCB 180 & $53.3 \pm 13.0$ & $58.7 \pm 9.5$ \\
PCB 209 & $4.6 \pm 2.0$ & $4.8 \pm 3.8$ \\
$o, p^{\prime}$-DDD & $21.8 \pm 0.7$ & $18.6 \pm 2.9$ \\
$o, p^{\prime}$-DDE & $2.9 \pm 0.5$ & $2.6 \pm 3.4$ \\
\hline
\end{tabular}

in Kuderna-Danish and the aliquots $(2 \mathrm{ml})$ were transferred to a glass column packed with $20 \mathrm{~g}$ of Florisil and dried by passing through nitrogen gas. Organochlorines adsorbed on Florisil were eluted with $150 \mathrm{ml}$ of $20 \%$ hexane-washed water in acetonitrile and transferred to a separatory funnel containing $600 \mathrm{ml}$ of hexane-washed water and $100 \mathrm{ml}$ of hexane. After partitioning, the hexane layer was concentrated, cleaned up with sulphuric acid, and passed through a $12 \mathrm{~g}$ Florisil packed glass column for separation.

Final determination of PCBs and OC-DDTs was carried out using a Varian 3600 gas chromatograph fitted with an electron capture detector (GC-ECD). All analyses used a fused-silica capillary column Supelco (length $30 \mathrm{~m}$, inside diameter $0.53 \mathrm{~mm}$ and film thickness $0.50 \mu \mathrm{m})$. The column oven was programmed from 60 to $160^{\circ} \mathrm{C}$, held for $10 \mathrm{~min}$, and then increased to $260^{\circ} \mathrm{C}$ at a rate of $2^{\circ} \mathrm{C} \mathrm{min}{ }^{-1}$ and held for $20 \mathrm{~min}$. Injector and detector temperatures were set at 260 and $280^{\circ} \mathrm{C}$ respectively. Nitrogen was used as carrier gas with $63.3 \mathrm{ml} \mathrm{min}{ }^{-1}$. The internal standard used for quantification of OC-DDTs and PCB congeners was tetrachloro-m-xylene. Detectable concentration range for the contaminants included in this study was from $1 \mathrm{ng} \mathrm{g}^{-1}$ (instrumental quantification limit) to $50000 \mathrm{ng} \mathrm{g}^{-1}$ (optimum linear limit). Concentrations of contaminants (means of 3 measurements) are presented as $n g \mathrm{~g}^{-1}$ on a wet weight basis.

Samples from liver, celomic wall and celomic fat were also taken and cultured on a variety of selective and non-selective media including blood agar (Oxoid), MacConkey agar (Oxoid), Baird Parker agar (Oxoid) for staphylococci, and Sabouraud Dextrose agar (Oxoid) for fungi and yeasts. All cultures were incubated at $25^{\circ} \mathrm{C}$ aerobically. 


\section{RESULTS}

At necropsy a generalized subcutaneous edema was observed. Large amount of adipose tissue in the celomic cavity showing very firm, yellow to orange irregular formations was observed (Fig. 1). At the cut surface the fat showed orange to brown irregular nodules and was mildly hyperhemic (Fig. 1). Fat samples did not float in the formalin solution. The liver was cranially displaced and presented a reduced size. Several nematode larvae were observed in the gastric serosa. No gross lesions were visible in other major organs.

Histologically, the celomic fat presented severe extensive degeneration and necrosis. Lesions ranged from the infiltration of necrotic fat by scarce multinucleated giant cells and numerous macrophages containing xylene-insoluble lipopigment inclusions to the presence of several granulomas characterized by an irregular central area consisting of necrotic fat showing variable amounts of lipopigment surrounded by numerous multinucleated giant cells (Fig. 2). In addition, granulomas consisting of varyingly enlarged as well as ruptured adipocytes surrounded by ceroid-containing macrophages were observed. Presence of ceroid pigment in the macrophages and in the areas of necrotic fat was confirmed by staining with ZN (Fig. 2, inset) and PAS stains. No microorganisms or parasites were identified in the lesions of the fat. Several granulomas associated a nematode larvae were observed in the lamina propria, submucosa, lamina muscularis and serosa of the stomach. No histological lesions were observed in other organs. All microbiological cultures were negative.

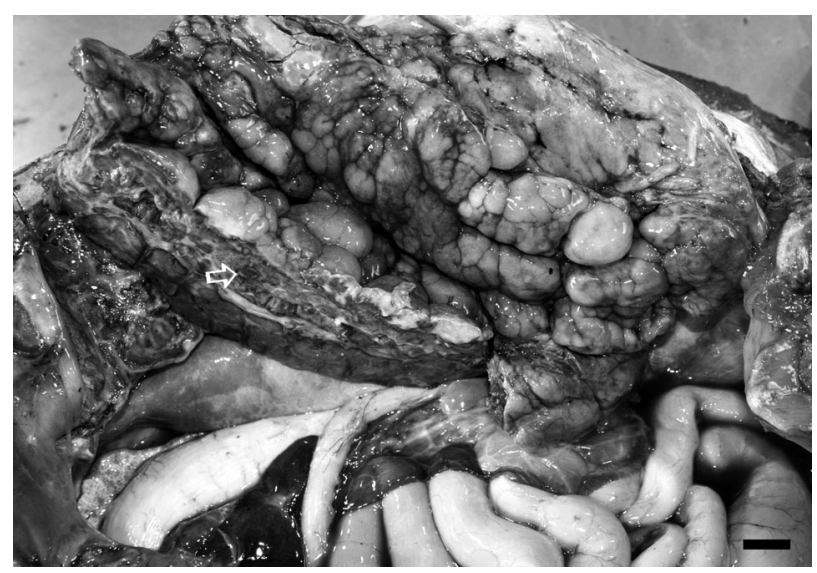

Fig. 1. Caretta caretta. Large amount of adipose tissue showing very firm irregular formations in the left part of the celomic cavity. Note the dark nodule (arrow) in the cut surface. Scale bar $=2.2 \mathrm{~cm}$

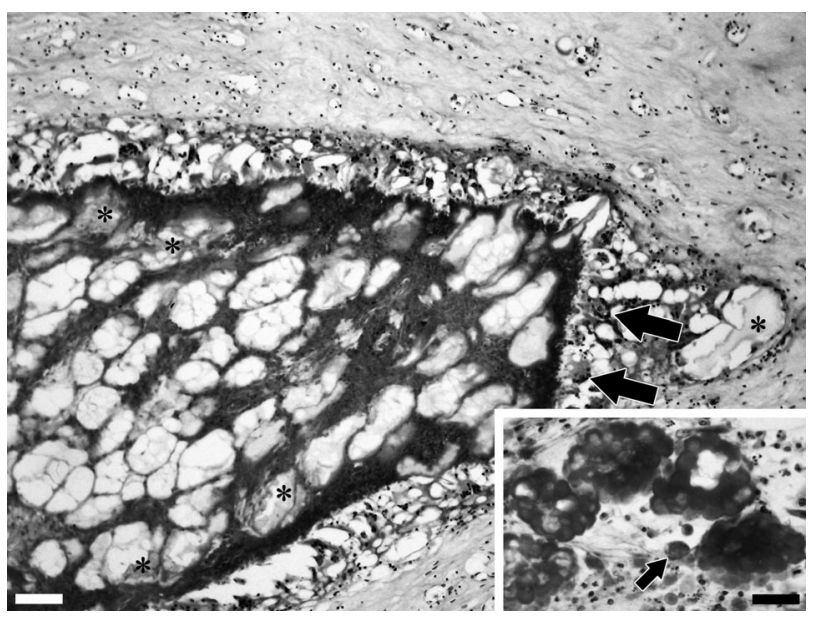

Fig. 2. Caretta caretta. Granuloma in the celomic fat characterized by a central area of fat necrosis with variable amounts of lipopigment (*) surrounded by numerous multinucleated giant cells (arrows). HE stain. Scale bar $=80 \mu \mathrm{m}$. Inset: Acid-fast staining of the ceroid pigment in areas of necrotic fat and within macrophages (arrow). ZN stain. Scale bar $=55 \mu \mathrm{m}$

Concentrations of PCBs and OC-DDTs in the celomic fat of this turtle are presented in Table 2.

\section{DISCUSSION}

Histological examination of the celomic adipose tissue of this turtle confirmed the diagnosis of pansteatitis. The presence of ceroid-laden macrophages and characteristic multinucleated giant cells surrounding degenerating and ruptured adipocytes as well as the associated granuloma formation are typical findings in all reptile species suffering from

Table 2. Caretta caretta. Concentration of PCBs and OCDDTs (ng g ${ }^{-1}$ wet wt) in the celomic fat of the loggerhead turtle suffering from pansteatitis. BDL: below detection limit $\left(1 \mathrm{ng} \mathrm{g}^{-1}\right)$

\begin{tabular}{|lcc|}
\hline & Contaminant & Concentration \\
\hline PCB & 28,31 & 5.1 \\
& 52 & 4.8 \\
& 101 & 7.8 \\
& 138 & 3170 \\
& 153 & 2830 \\
& 180 & 980 \\
$o, p^{\prime}-\mathrm{DDT}$ & 209 & 1190 \\
$o, p^{\prime}-\mathrm{DDD}$ & & 6.3 \\
$o, p^{\prime}-\mathrm{DDE}$ & & 5.9 \\
& & $\mathrm{BDL}$ \\
\hline
\end{tabular}


pansteatitis (Larsen et al. 1983, Huchzermeyer 2003, Manawatthana \& Kasorndorkbua 2005, Bouwman et al. 2009). In addition, similar lesions have been reported in several fish species (Begg et al. 2000, Goodwin 2006, Roberts \& Agius 2008, Huchzermeyer et al. 2011). This is the first report of pansteatitis in a wild sea turtle.

In a study on the lipid properties of pansteatitisaffected wild Nile crocodiles the authors concluded that the hard texture of celomic fat with steatitis was not caused by the fatty acid composition, but could be ascribed to the mononuclear cellular infiltrate associated with the inflammatory process (Osthoff et al. 2010). Buoyancy problems are common in sea turtles and are not always associated with pulmonary lesions (Orós et al. 2005). In the absence of pulmonary and intestinal lesions the large amount of very hard fat irregularly distributed mainly in the caudal part of the celomic cavity observed in this turtle could explain the abnormal floatation.

Pansteatitis has been defined as a nutritional disorder characterized by inflammation of adipose tissue and deposition of ceroid pigment in fat cells as a result of vitamin E deficiency (Osthoff et al. 2010). Fytianou et al. (2006) provided experimental evidence linking the disease to the consumption of high levels of unsaturated fatty acids or oxidized fats that deplete the vitamin $\mathrm{E}$.

Pansteatitis in reptiles has been previously associated with an exclusive fish diet in captive alligators (Larsen et al. 1983), consumption of large numbers of dead and rancid fish in farmed crocodiles (Huchzermeyer 2003), and exclusive frozen fish diet for more than 20 yr without proper vitamin supplementation in captive olive ridley sea turtles (Manawatthana \& Kasorndorkbua 2005). In 2008 an episode of crocodile pansteatitis occurred in the Kruger National Park (KNP), South Africa. The primary cause of this outbreak remains unknown, but it is speculated that the deaths were triggered by a combination of environmental and dietary factors (Bouwman et al. 2009). Sediment from the rivers in the KNP contained traces of dioxin-like substances, some pesticides (DDT and $\mathrm{HCH})$, polycyclic aromatic hydrocarbons, and polybrominated flame-retardants. However, the levels of organochlorine contaminants found in the fat of dead crocodiles were not particularly high, and none of their methylsulfone metabolites were detected (Bouwman et al. 2009). In addition, Begg et al. (2000) reported steatitis in 2 species of wild marine fish, with suspicion of a pollution-related etiology, and changes in antioxidant parameters in Nile tilapia Oreochromis niloticus have been linked to the effects of oxidative stress from polluted water (Bainy et al. 1996).

The high levels of PCB 138, 153, 180209 found in the celomic fat of this loggerhead turtle are very remarkable. In a previous study on PCBs in 30 loggerhead turtles stranded in the Canary Islands, the mean concentrations in fat for PCB 138, 153, 180 209 were 83, 133, 217, and $15 \mathrm{ng} \mathrm{g}^{-1}$, respectively, and the highest individual concentrations in fat for PCB 138, 153, 180209 were 370.5, 2600, 5006, and $218 \mathrm{ng} \mathrm{g}^{-1}$, respectively (Orós et al. 2009). Authors concluded that tissues from those turtles contained higher levels of PCBs than those reported in turtles from other geographical regions. The levels of PCB 138, 153209 in the turtle from the current study are the highest PCB values reported for a sea turtle (D'Ilio et al. 2011). In addition, these values were similar to those reported for bottlenose dolphins Tursiops truncatus stranded in the Canary Islands (Carballo et al. 2008), suggesting that this turtle was feeding on fish.

The concentrations of $o, p^{\prime}-\mathrm{DDT}, o, p^{\prime}-\mathrm{DDE}$, and $o, p^{\prime}$-DDD in the fat of this loggerhead turtle were lower than those reported previously in a survey on 23 loggerhead turtles stranded in the Canary Islands (Monagas et al. 2008). However, because of the specific research interest of our department in the $o, p^{\prime}$ DDT as estrogenic environmental contaminant compared to synthetic estrogens, $p, p^{\prime}$-isomers were not measured. And, according to the bibliography, $p, p^{\prime}-$ DDE is the pesticide present in the greatest concentrations in sea turtles due to its highly persistent nature (D'Ilio et al. 2011).

Sea turtle blood is also a suitable alternative to fatty tissues for measuring organochlorine contaminants because blood concentrations reasonably represent those observed in the paired fat samples (Keller et al. 2004a). Paired blood plasma samples would have been informative to clarify contaminant distribution, as deposition to and remobilization from fat stores could have been heavily impacted by pansteatitis.

PCBs are organic pollutants that persist and bioaccumulate in the environment. Studies on the effects of these contaminants on diseases and lesions of sea turtles are scarce (Keller et al. 2004b, Swarthout et al. 2010). Previous studies have shown that they increase oxidative stress in many model systems including mammals (Wells et al. 1997), birds (Jin et al. 2001) and fish (Otto \& Moon 1996). In fact, changes in the oxidative status due to the exposure to contaminants, such as certain PCB congeners (e.g. non-ortho-substituted and mono-ortho-substituted congeners), leads to generation of reactive oxygen 
species and this has been linked with the development of lipid peroxidation and immunotoxicity in aquatic organisms (Coteur et al. 2001, Shimizu et al. 2007). There is growing evidence that both mechanisms can be involved in the development of steatitis (Begg et al. 2000, Fromenty et al. 2004). Although a nutritional cause (i.e. consumption of an abnormal quantity of oily fish with a high concentration of unsaturated fatty acids) for the pansteatitis observed in this wild loggerhead turtle cannot be ruled out, the high levels of PCBs detected in the celomic fat could have induced lipid peroxidation in adipocytes of this animal, resulting in cell damage, deposition of ceroid pigment and inflammatory response. The cause of the high levels of PCBs in this turtle could be a diet of higher trophic level, lipid-rich prey. However, the major diet components for loggerhead turtles in this geographical area are epipelagic salps, gastropods, pelagic coelenterates (primarily siphonophores and to a lesser extent Scyphomedusae and Hydromedusae), and barnacles (Van Nierop \& den Hartog 1984). Because loggerhead turtles are primarily carnivorous opportunistic feeders, feeding of some loggerheads primarily on fisheries bycatch could not be discarded.

Because data of the effects of PCBs on diseases and lesions of sea turtles are scarce, this report, although based on a single individual, provides an important addition to the association between PCBs and disease in sea turtles, and suggests the need to investigate the role of these contaminants in the pathogenesis of pansteatitis in vertebrates.

Acknowledgements. The authors thank P. Castro, Department of Morphology, University of Las Palmas de Gran Canaria, for technical assistance.

\section{LITERATURE CITED}

Bainy ACD, Saito E, Carvalho PSM, Junqueira VBC (1996) Oxidative stress in gill, erythrocytes, liver and kidney of Nile tilapia (Oreochromis niloticus) from a polluted site. Aquat Toxicol 34:151-162

Begg GS, Bruno DW, McVicar AH (2000) The histopathology and ultrastructure of steatitis affecting common dab Limanda limanda. Dis Aquat Org 41:123-133

Blanco JC, González JL (1992). Libro rojo de los vertebrados españoles. Colección Técnica ICONA, Ministerio de Agricultura, Pesca y Alimentación, Madrid

Bouwman H, Nieuwoudt C, Pieters R, Quinn L and others (2009) The curious case of the dying crocodiles in the Kruger National Park, South Africa. In: Proc 12th EuCheMS Int Conf Chem Environ, 14-17 June 2009, Stockholm, p 14

- Carballo M, Arbelo M, Esperón F, Mendez M, de la Torre A, Muñoz MJ (2008) Organochlorine residues in the blub- ber and liver of bottlenose dolphins (Tursiops truncatus) stranded in the Canary Islands, North Atlantic Ocean. Environ Toxicol 23:200-210

> Coteur G, Danis B, Fowler SW, Teyssié JL, Dubois Ph, Warnau M (2001) Effects of PCBs on reactive oxygen species (ROS) production by the immune cells of Paracentrotus lividus (Echinodermata). Mar Pollut Bull 42:667-672

D'Ilio S, Mattei D, Blasi MF, Alimonti A, Bogialli S (2011) The occurrence of chemical elements and POPs in loggerhead turtles (Caretta caretta): an overview. Mar Pollut Bull 62:1606-1615

> Flint M, Patterson-Kane JC, Limpus CJ, Work TM, Blair D, Mills PC (2009) Postmortem diagnostic investigation of disease in free-ranging marine turtle populations: a review of common pathologic findings and protocols. J Vet Diagn Invest 21:733-759

Fromenty B, Robin MA, Igoudjil A, Mansouri A, Pessayre D (2004) The ins and outs of mithocondrial dysfunction in NASH. Diabetes Metab 30:121-138

> Fytianou A, Koutinas AF, Saridomichelakis MN, Koutinas CK (2006) Blood $\alpha$-tocopherol, selenium and glutathione peroxidase changes and adipose tissue fatty acid changes in kittens with experimental steatitis (yellow fat disease). Biol Trace Elem Res 112:131-143

German AJ, Foster AP, Holden D, Hotston Moore A, Day MJ, Hall EJ (2003) Sterile nodular panniculitis and pansteatitis in three weimaraners. J Small Anim Pract 44:449-455

$>$ Goodwin AE (2006) Steatitis, fin loss and skin ulcers of channel catfish, Ictalurus punctatus (Rafinesque), fingerlings fed salmonid diets. J Fish Dis 29:61-64

Huchzermeyer FW (2003) Crocodiles: biology, husbandry and diseases. CABI Publishing, Wallingford

> Huchzermeyer KDA, Govender D, Pienaar DJ, Deacon AR (2011) Steatitis in wild sharptooth catfish, Clarias gariepinus (Burchell), in the Olifants and Lower Letaba Rivers in the Kruger National Park, South Africa. J Fish Dis 34:489-498

IUCN (International Union for Conservation of Nature and Natural Resources) (2012) 2012 IUCN red list of threatened species. www.redlist.org

- Jin X, Kennedy SW, Di Muccio T, Moon TW (2001) Role of oxidative stress and antioxidant defense in $3,3^{\prime}, 4^{\prime} 4^{\prime}$, 5-pentachlorobiphenyl-induced toxicity and speciesdifferential sensitivity in chicken and duck embryos. Toxicol Appl Pharmacol 172:241-248

Keller JM, Kucklick JR, Harms CA, McClellan-Green PD (2004a) Organochlorine contaminants in sea turtles: correlations between whole blood and fat. Environ Toxicol Chem 23:726-738

Keller JM, Kucklick JR, Stamper MA, Harms CA, McClellan-Green PD (2004b) Associations between organochlorine contaminant concentrations and clinical health parameters in loggerhead sea turtles from North Carolina, USA. Environ Health Perspect 112:1074-1079

> Larsen RE, Buergelt C, Cardeilhac PT, Jacobson ER (1983) Steatitis and fat necrosis in captive alligators. J Am Vet Med Assoc 183:1202-1204

Manawatthana S, Kasorndorkbua C (2005) Steatitis and vitamin E deficiency in captive olive ridley turtles (Lepidochelys olivacea). In: Arai N (ed) Proc 6th SEASTAR2000 workshop, Bangkok, p 85-87

- Monagas P, Orós J, Araña J, González-Díaz OM (2008) Organochlorine pesticide levels in loggerhead turtles (Caretta caretta) stranded in the Canary Islands, Spain. Mar Pollut Bull 56:1949-1952 
Orós J, Torrent A (2001) Manual de necropsia de tortugas marinas. Ediciones del Cabildo de Gran Canaria, Las Palmas de Gran Canaria

Orós J, Torrent A, Calabuig P, Déniz S (2005) Diseases and causes of mortality among sea turtles stranded in the Canary Islands, Spain (1998-2001). Dis Aquat Org 63: $13-24$

Orós J, González-Díaz OM, Monagas P (2009) High levels of polychlorinated biphenyls in tissues of Atlantic turtles stranded in the Canary Islands, Spain. Chemosphere 74: $473-478$

Orós J, Arencibia A, Monagas P (2012) Anthropogenic causes of mortality on sea turtles in the Canary Islands: a multidisciplinary approach to the conservation of endangered sea turtles. In: Cosgrove MJ, Roe SA (eds) Turtles: anatomy, ecology and conservation. Nova Science Publishers, New York, NY, p 53-86

Osthoff G, Hugo A, Bouwman H, Buss P, Govender D, Joubert CC, Swarts JC (2010) Comparison of the lipid properties of captive, healthy wild, and pansteatitisaffected wild Nile crocodiles (Crocodylus niloticus). Comp Biochem Physiol A 155:64-69

Otto DME, Moon TW (1996) Phase I and II enzymes and antioxidant responses in different tissues of brown bullheads from relatively polluted and non-polluted systems. Arch Environ Contam Toxicol 31:141-147

Roberts RJ, Agius C (2008) Pansteatitis in farmed northern

Editorial responsibility: Thomas Braunbeck,

Heidelberg, Germany bluefin tuna, Thunnus thynnus (L.), in the eastern Adriatic. J Fish Dis 31:83-88

Shimizu K, Ogawa F, Thiele JJ, Bae S, Sato S (2007) Lipid peroxidation is enhanced in Yusho victims 35 years after accidental poisoning with polychlorinated biphenyls in Nagasaki, Japan. J Appl Toxicol 27:195-197

> Swarthout RF, Keller JM, Peden-Adams M, Landry AM, Fair PA, Kucklick JR (2010) Organohalogen contaminants in blood of Kemp's ridley (Lepidochelys kempii) and green sea turtles (Chelonia mydas) from the Gulf of Mexico. Chemosphere 78:731-741

Tanabe S, Sung JK, Choi DY, Baba N, Kiyota M, Tatsukawa $\mathrm{R}$ (1994) Persistent organochlorine residues in northern fur seal from the Pacific coast of Japan since 1971. Environ Pollut 85:305-314

Van Nierop MM, den Hartog JC (1984) A study on the gut contents of 5 juvenile loggerhead turtles, Caretta caretta (Linnaeus) (Reptilia, Cheloniidae), from the south-eastern part of the North Atlantic Ocean, with emphasis on coelenterate identification. Zool Meded Leiden 59:35-54

Wells PG, Kim PM, Laposa RR, Nicol CJ, Parman T, Winn LM (1997) Oxidative damage in chemical teratogenesis. Mutat Res 396:65-78

Work TM, Balazs GH, Rameyer RA, Morris RA (2004) Retrospective pathology survey of green turtles Chelonia mydas with fibropapillomatosis in the Hawaiian Islands, 1993-2003. Dis Aquat Org 62:163-176

Submitted: May 29, 2012; Accepted: October 30, 2012

Proofs received from author(s): January 22, 2013 